\title{
Sistem Monitoring Panel Surya Secara Realtime Berbasis Arduino Uno Dhelmiga Pratama ${ }^{1 *}$, Asnil ${ }^{1}$
}

\author{
${ }^{1}$ Jurusan Teknik Elektro, Fakultas Teknik, Universitas Negeri Padang \\ *dhelmigapratama@gmail.com
}

(Diajukan: 13 Januari 2021, direvisi: 29 Januari 2021, disetujui: 31 Januari 2021)

\begin{abstract}
Abstrak
Pemantauan terhadap performa panel surya sangat perlu dilakukan untuk menilai kinerja sebuah panel surya pada kondisi lingkungan yang nyata. Penelitian ini bertujuan memberikan suatu teknik baru pemantauan secara langsung dan real time untuk arus, tegangan, suhu, temperature dan radiasi matahari. Untuk memenuhi keperluan tersebut, sistem monitoring performa panel surya yang dirancang dilengkapi dengan sensor pengukur arus, tegangan, suhu, temperature dan radiasi matahari yang telah dikalibrasi, system monitoring dengan menggunakan PLX DAQ yang diintegrasikan ke Microsoft Excel. Perancangan sistem berbasis mikrokontroler Arduino Uno ini dihubungkan ke computer. Hasil dari sistem monitoring ini adalah pengukuran dari setiap sensor dapat diproses secara langsung dan ditampilkan dalam bentuk grafik pada kondisi real time serta dapat memonitor performa tersebut. Informasi mengenai tegangan dan arus dari panel surya yang dikumpulkan pada kondisi real time dapat diperoleh langsung melalui dokumen Excel yang datanya didapatkan dari database. Fasilitas ini memberikan kemudahan untuk pengolahan data selanjutnya.
\end{abstract}

Kata Kunci: monitoring, arus, tegangan, daya, suhu, kelembapan, radiasi matahari

\section{Abstract}

Monitoring the performance of solar panels is very necessary to assess the performance of a solar panel in real environmental conditions. This research aims to provide a new technique for direct and real time monitoring of currents, voltages, temperatures, temperatures and solar radiation. To meet these requirements, a solar panel performance monitoring system designed to be equipped with calibrated sensors for measuring current, voltage, temperature, temperature and solar radiation, monitoring system using PLX DAQ which is integrated into Microsoft Excel. The Arduino Uno microcontroller based system design is connected to a computer. The result of this monitoring system is that the measurement of each sensor can be processed directly and displayed in graphical form in real time conditions and can monitor the performance. Information about the voltages and currents of solar panels that are collected in real time can be obtained directly through an Excel document whose data is obtained from the database. This facility makes it easy for further data processing.

Keywords: monitoring, current, voltage, power,temperature and humidity, irradiation 


\section{PENDAHULUAN}

Saat ini seluruh dunia mulai gencar mencari sumber energi terbarukan, mulai dari air, udara, sinar matahari, ombak laut dll. Diantara Pemanfaatan energi alternative antara lain adalah matahari. Matahari adalah sumber energi alternative terbesar yang di dapat oleh bumi, dari seluruh cahaya matahari yang di pancarkan ke bumi hanya $30 \%$ yang kembali keluar angkasa. Oleh karena itu diharapkan dapat membantu memenuhi kebutuhan energi listrik dengan menggunakan sel surya sebagai pengubah radiasi matahari menjadi listrik atau bisaa disebut dengan Pembangkit Listrik Tenaga Surya (PLTS)[1], [2].

Panel surya adalah suatu peralatan yang merupakan implementasi dari efek fotovoltaik yang mengkonversi cahaya matahari menjadi energi listrik. Panel surya adalah suatu kesatuan modul yang didalamnya terdapat peralatan tambahan lainnya. Tegangan output yang dihasilkan sel surya berubah-ubah sesuai dengan intensitas cahaya yang jatuh pada permukaannya. Perubahan nilai tegangan ini akan menghambat sistem charging [3],[4]. Untuk mencegah kerusakan dan penurunan energi yang dihasilkan oleh panel surya dibutuhkan sensor untuk memonitoring aktivitas sekaligus memberikan notifikasi ketika kinerja telah menurun, Akuisisi data pada panel surya akan memudahkan pengumpulan data-data dalam monitoring kinerja sistem yang dibutuhkan untuk waktu yang lama, dimana pengukuran perlu dilakukan menggunakan parameter masukan dan keluaran untuk melihat karakteristik dan kinerja dari panel surya. Parameter yang digunakan yaitu intensitas cahaya matahari dengan satuan lux atau Watt/m2, suhu $\left({ }^{\circ} \mathrm{C}\right)$, temperature, arus (Amper) dan tegangan (Volt) [5], [6]. Pada panel surya tersebut. Pemantauan dalam kondisi realtime diperlukan untuk meningkatkan keandalan, evaluasi dan implementasi . Selain untuk uraian karakteristik yang diperoleh juga berguna untuk menentukan kebutuhan beban [7]. Pada Gambar 1 dapat dilihat bentuk kurva I-V sedangkan pada Gambar. 2 menunjukkan kurva P-V dari panel surya untuk berbagai variasi iradiasi dengan suhu konstan. Pada kurva I-V, bisa terlihat bahwa arus yang dihasilkan bertambah bila ada peningkatan radiasi yang diterima oleh panel surya. Sedangkan di sisi lainnya tegangan terlihat relatif konstan meskipun ada peningkatan dalam nilai arus.

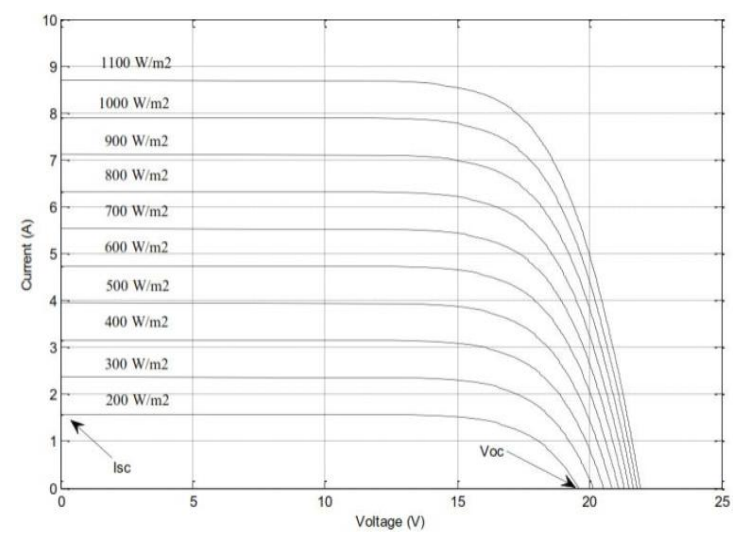

Gambar 1. Kurva I-V dengan suhu dan radiasi bervariasi [8]. 


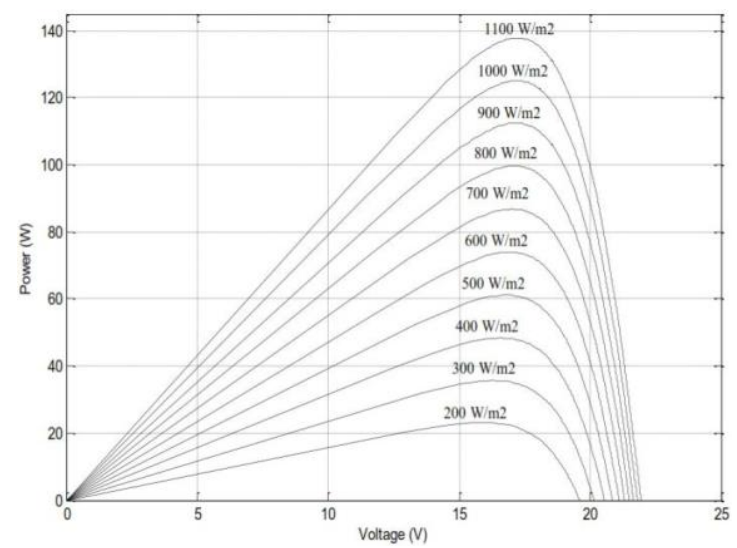

Gambar 2. Kurva P-V dengan temperature konstan dan radiasi bervariasi [8].

Pada gambar 3 dan gambar 4. Energi maksimum yang dihasilkan berada dititik suhu terendah, sedangkan energi minimum adalah saat nilai maksimum suhu. Variasi suhu yang terjadi ketika radiasi konstan tidak mempengaruhi arus yang dihasilkan dalam arti arusnya relatif konstan. Jika suhu lebih rendah, maksimal daya lebih tinggi sedangkan tegangan rangkaian terbuka lebih besar, tetapi suhu yang lebih rendah memberikan lebih sedikit arus hubung singkat lebih rendah [8].

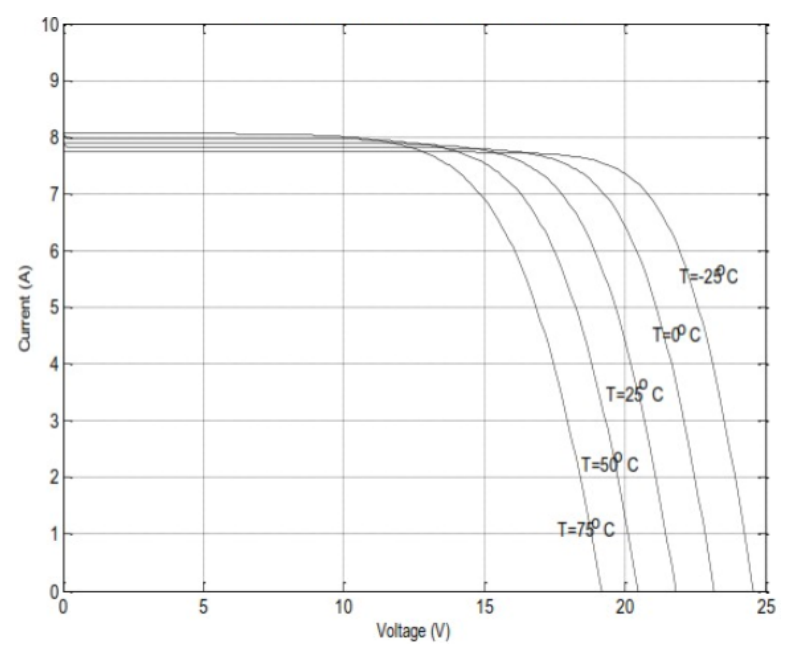

Gambar 3. Kurva I-V dengan radiasi konstan dan suhu beragam [8].

Kinerja sebuah panel surya yang ditempatkan pada suatu kondisi lingkungan tertentu dapat ditentukan dengan memantau langsung parameter keluarannya seperti tegangan, arus dan daya. Dari hasil pemantauan tersebut dapat diperoleh informasi apakah pemasangan panel surya sudah sesuai dan menghasilkan daya keluaran yang diharapkan. Data ini tidak dapat diambil langsung pada kondisi real time. Jika data parameter keluaran panel surya dapat diperoleh secara real time dalam bentuk grafik maka pengguna tehnologi panel surya dapat mengatur sendiri pemakaian energi dan beban listriknya [9]. 


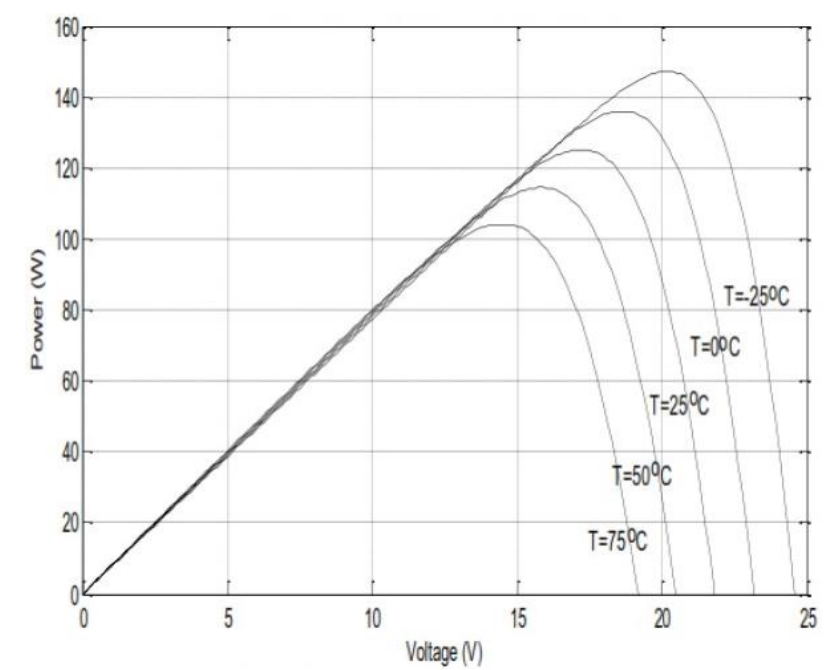

Gambar 4. Kurva P-V dengan radiasi konstan dengan suhu beragam [8].

Pada penelitian sebelumnya, sistem monitoring output pencatatan data pada panel surya berbasis mikrokontroler Arduino dapat melakukan monitoring output dari panel surya menggunakan sensor arus dan sensor tegangan untuk mendapatkan nilai arus, tegangan, dan nilai daya output dari panel surya dengan data yang secara otomatis tersimpan pada SD Card [10], [11]. Metode pemantauan panel surya saat ini hanya mengumpulkan data parameter keluaran panel surya dalam bentuk text file dengan format tertentu. Data ini tidak dapat diambil langsung pada kondisi real time [12], [13]. Dari hasil sistem pemantauan kinerja panel surya yang dirancang dilengkapi dengan sensor pengukur arus, tegangan, suhu, temperature dan radiasi matahari yang telah dikalibrasi, sistem akuisisi data yang diintegrasikan ke spreadsheet Excel menggunakan program aplikasi PLX-DAQ dan kartu memori sebagai penyimpan data cadangan. Sistem berbasis mikrokontroler Arduino dihubungkan ke komputer melalui port serial.[14], [15].

\section{METODA}

\section{Analisa Sistem}

Dari hasil analisa, diusulkan aplikasi yang dapat mengatasi masalah-masalah yang sudah teridentifikasi. Usulan-usulan tersebut tersusun menjadi sebuah diagram yang akan terbentuk menjadi sebuah sistem usulan dalam melakukan monitoring dan notifikasi kinerja panel surya yang ditunjukkan diagram alir pada Gambar 5. Untuk skema pengiriman data dari sensor menuju ke PC. Sebelum sampai ke PC, data melalui beberapa tahap diantaranya pemrosesan melalui mikrokontroler Arduino. 


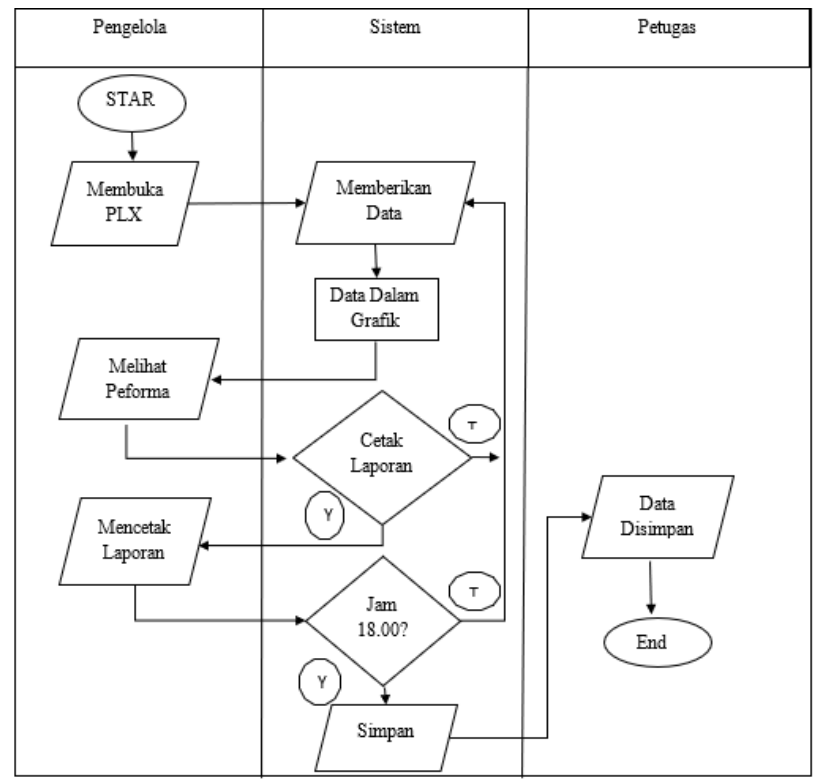

Gambar 5. Analisa Sistem

\section{Pengembangan Perangkat Keras}

Kebutuhan perangkat keras dalam membangun aplikasi ini dibagi menjadi perangkat keras administrator sistem dan perangkat keras pengguna. Bagian ini menjelaskan mengenai rangkaian dan proses kerja dari perangkat keras sistem yang akan dibangun, seperti bagaimana interaksi sensor yang terdapat pada sistem monitoring kinerja pada panel surya terhadap aplikasi hingga menghasilkan informasi kepada pengguna. Komponen yang diperlukan pada pembuatan sistem tersebut digunakan untuk membuat prototype sistem monitoring kinerja panel surya. Komponen-komponen tersebut diantaranya: Arduino, ACS712, DHT22, BH1750, sensor tegangan, kabel listrik, solar charge controller, accumulator, terminal listrik dan lain-lain. Pengembangan model sistem monitoring kinerja panel surya seperti pada gambar 6 . 


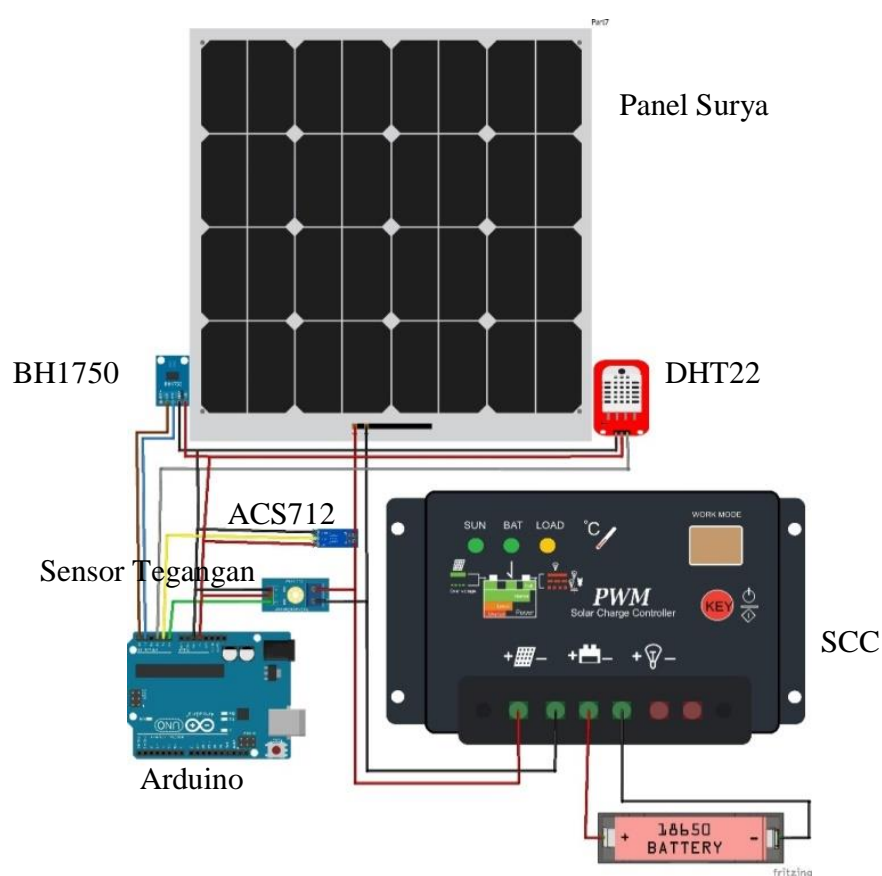

Gambar 6. Skema Rangkaian

\section{Sensor Tegangan}

Untuk dapat membaca tegangan yang dihasilkan oleh panel surya, maka diperlukan sensor tegangan untuk mengonversi data analog tegangan ke data tegangan digital untuk di proses oleh Arduino Uno. Sensor tegangan umumnya berupa sebuah rangkaian pembagi tegangan atau yang bisaa disebut voltage divider. Proses pengambilan data dari sensor tegangan sesuai dengan diagram alir pada gambar 7

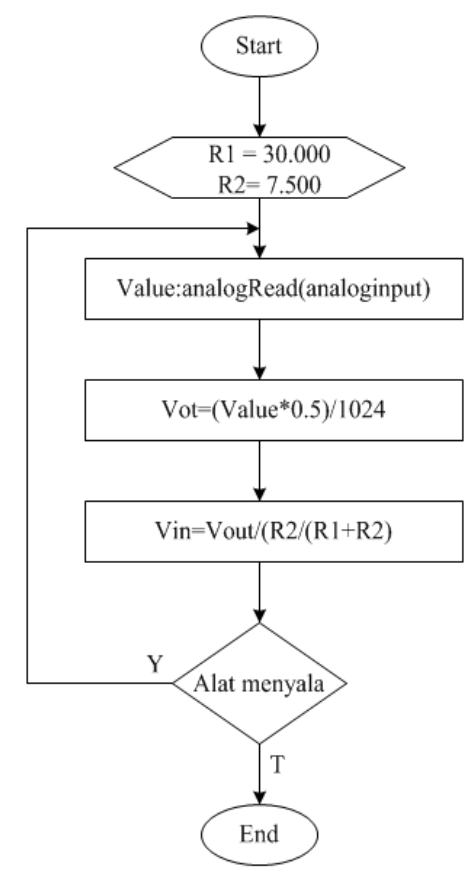

Gambar 7. Proses pengambilan data sensor tegangan 


\section{Sensor ACS 712}

Mengkoneksikan sensor arus ACS712 dengan arduino yaitu dimana tegangan 5V arduino dihubungkan melalui kabel merah ke Pin Vcc sensor arus ACS712, kemudian Ground arduino dihubungkan melalui kabel biru ke Pin GND sensor arus ACS712 dan Analog Read (A0) arduino dihungkan ke pada pin sinyal output sensor arus ACS712. Proses pengambilan data sensor ACS 712 sesuai dengan diagram alir pada gambar 8 .

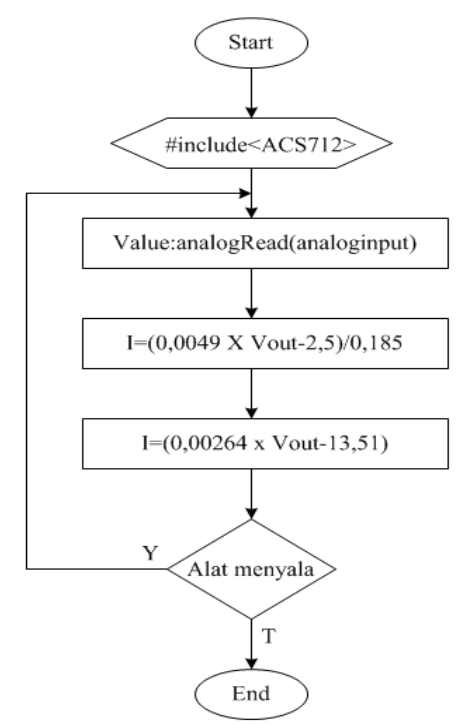

Gambar 8. Proses pengambilan data sensor ACS 712

\section{Sensor DHT 22}

DHT22 atau juga dikenal sebagai AM2302 adalah sensor yang dapat mengukur suhu dan kelembaban udara di sekitarnya.Sensor ini lebih akurat dan presisi dalam hal pengukuran di banding DHT11. Proses pengambilan data dari sensor DHT22 sesuai dengan diagram alir pada gambar 9.

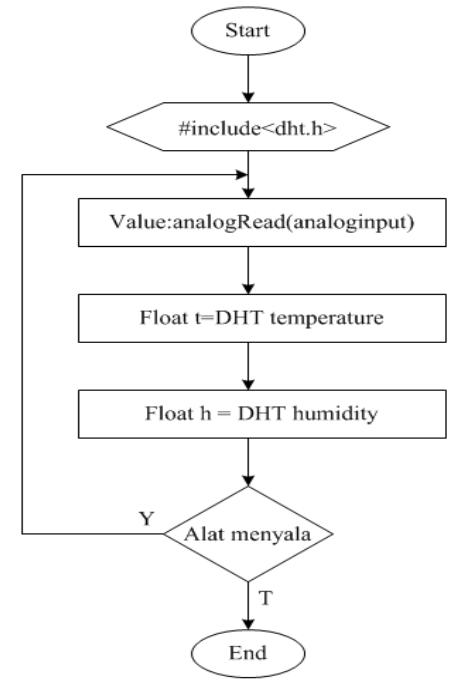

Gambar 9. Proses Pengambilan Data Sensor BH 1750 


\section{Sensor BH 1750}

Pengukur intensitas cahaya pada panel surya maka dibutuhkan sensor BH 1750. BH1750 adalah sebuah IC sensor yang digunakan untuk mengukur intensitas cahaya sekitar dalam ukuran atau satuan lux.

\section{HASIL DAN PEMBAHASAN}

Gambar 10 merupakan perangkat keras monitoring panel surya menggunakan system tracker untuk optimalisasi panel surya dalam menangkap cahaya matahari, pada system tracker ini menggunakan dua motor actuator sebagai penggerak vertikal dan horizontal.

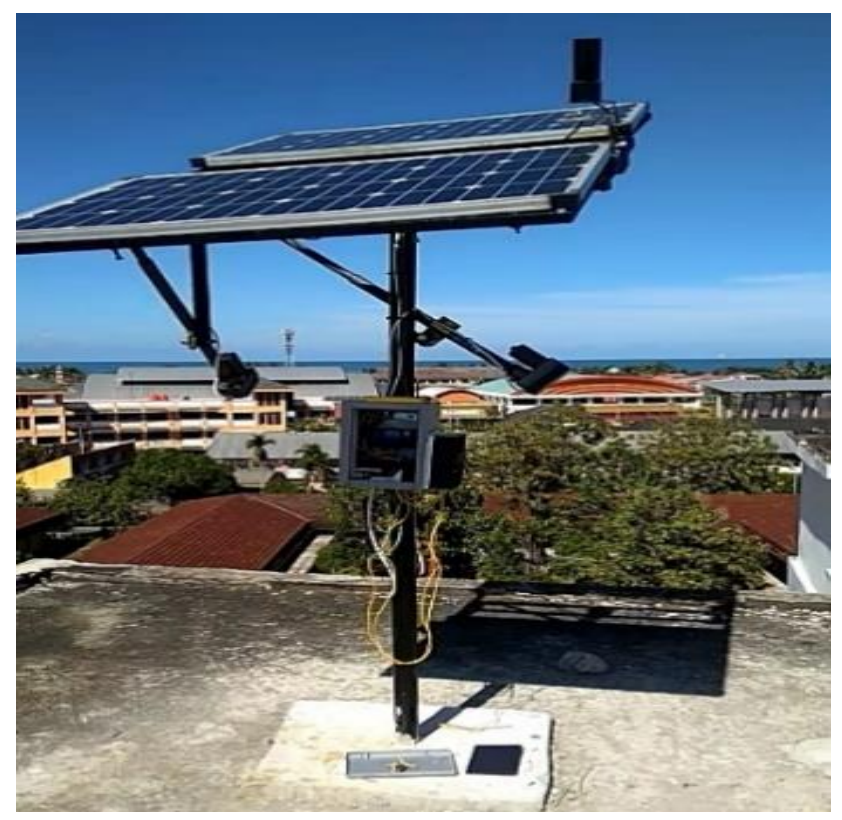

Gambar 10. Solar Tracker

Pada perangkat lunak menggunakan PLX DAQ untuk mengetahui dan memonitor data sensor yang dikirim arduino. Data yang dimonitoring oleh PLX DAQ berupa arus, tegangan, suhu, temperatur dan radiasi matahari.

Halaman utama PLQ DAQ merupakan halaman yang diakses apabila user telah masuk ke aplikasi PLQ DAQ seperti pada gambar 11. Halaman utama terdiri dari fiturfitur antara lain menampilkan reset, reset timer, clear colomns. Pada tampilan monitoring terdapat fitur view yang di-update secara real time sesuai dengan arus, tegangan, daya, temperature kelembaban, lux yang dihasilkan pada panel surya. Sumbu $\mathrm{X}$ dari grafik merupakan waktu tiap 5 menit, sedangkan sumbu Y dari grafik merupakan data yang dihasilkan 


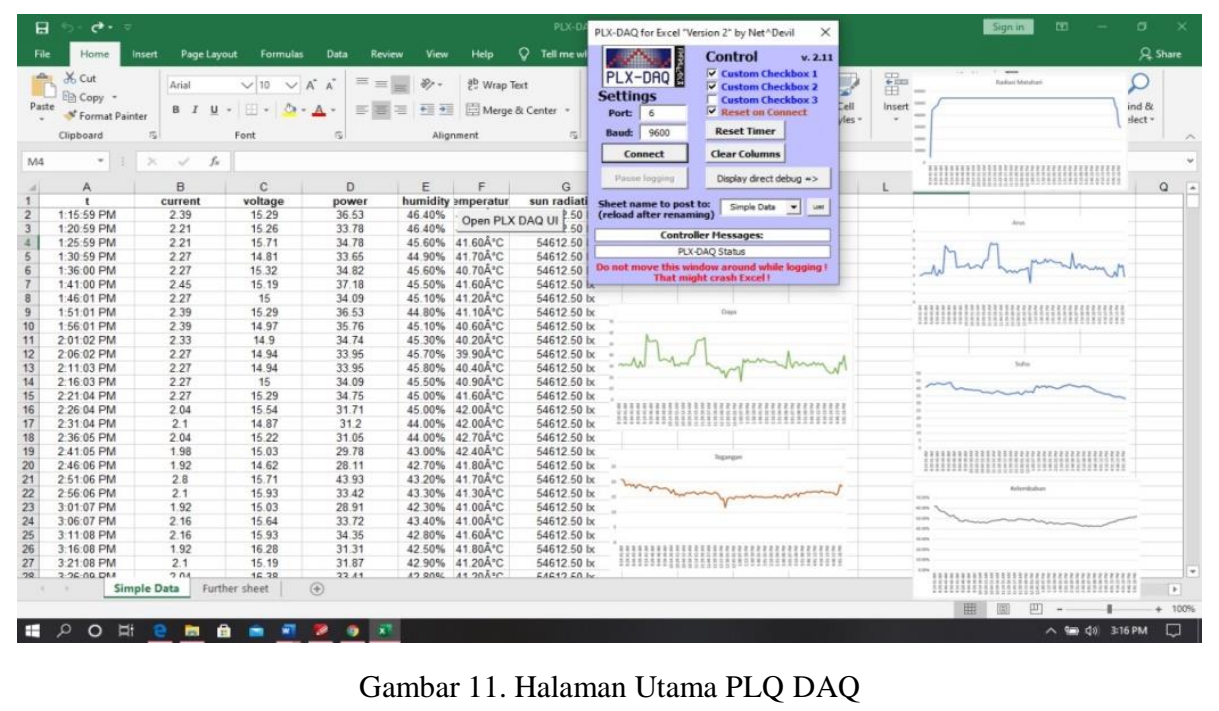

\section{Hasil Uji Validitas}

Analisa dilakukan berupa pengambilan data dari sensor Analisa statistik inferensial yang dilakukan berupa analisa perbedaan antara pengujian tegangan, arus, suhu, temperature, dan radiasi matahari. Pada sampel panel surya yang dilakukan tanpa menggunakan sensor atau menggunakan multimeter dan dengan menggunakan sensor. Daya yang dihasilkan merupakan hasil dari perhitungan menggunakan persamaan 1

$$
P=V \boldsymbol{x} I
$$

Berdasarkan hasil uji signifikansi, selisih antara hasil uji tanpa sensor dengan hasil menggunakan sensor tidak terlalu besar. Hal ini dikarenakan sensor dapat berkerja sesuai. yang diharapkan. Analisis pada monitoring arus dan tegangan tiap 5 menit, diperlihatkan pada hasil pembacaan sensor yang telah dikonversi kedalam grafik.

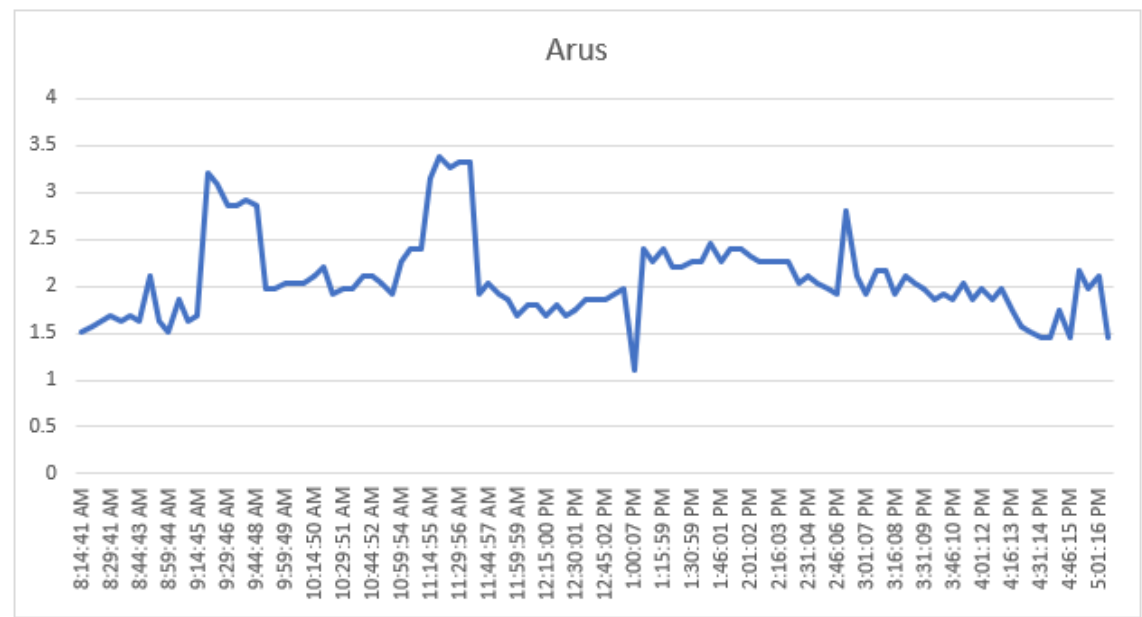

Gambar 12. Grafik Sensor Arus

Seperti yang dilihat pada gambar 12 pada awal pengambilan data pukul 8:14 sensor ACS712 menunjukan angka 1.5A hal ini dikarenakan panel surya menggunakan 
sistem tracker sebagai penggerak pada panel surya, sehingga pada awal pengambilan data tidak diawali dari 0 A. Pada Pukul 9:29 dan pukul 11:29, menunjukan grafik tertinggi, pukul 1:00 menunjukan grafik terendah dari sensor arus ACS712, hal ini dikarenakan beberapa faktor seperti penurunan atau kenaikan dari suhu dan temperature.

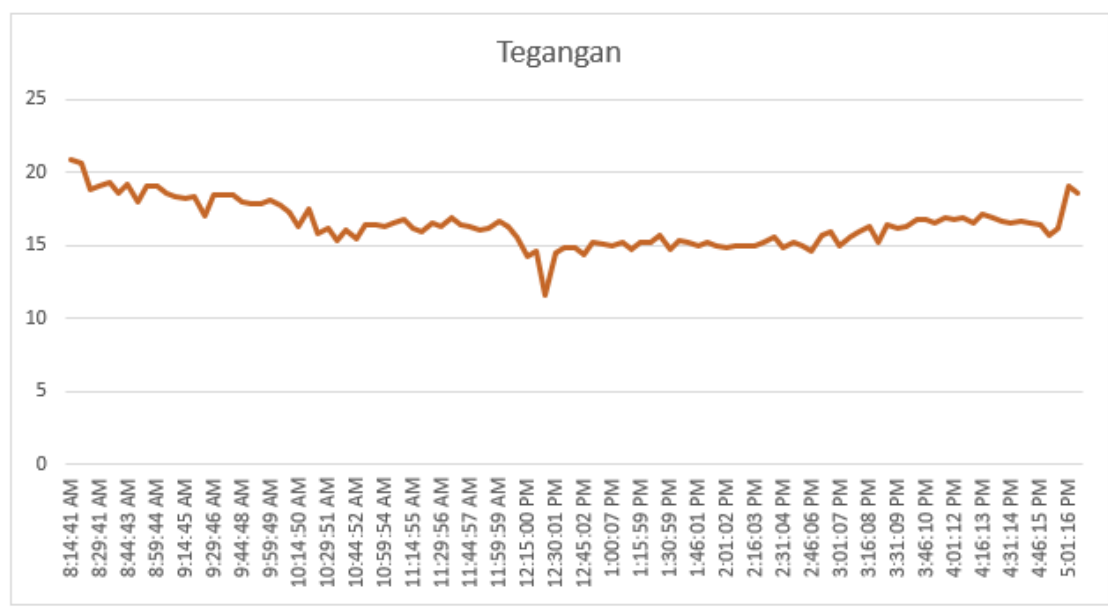

Gambar 13. Grafik sensor Tegangan

Pada gambar 13. Grafik sensor tegangan menunjukan grafik yang signifikan dari pukul 8:14 dengan tegangan $21 \mathrm{~V}$ sampai pukul 5:01 dengan tegangan $19 \mathrm{~V}$, pada rentang waktu tersebut terdapat penambahan dan penurunan tegangan panel surya, hal ini disebabkan oleh beberapa faktor, diantaranya adalah kenaikan dan penurunan suhu dan temperatur.

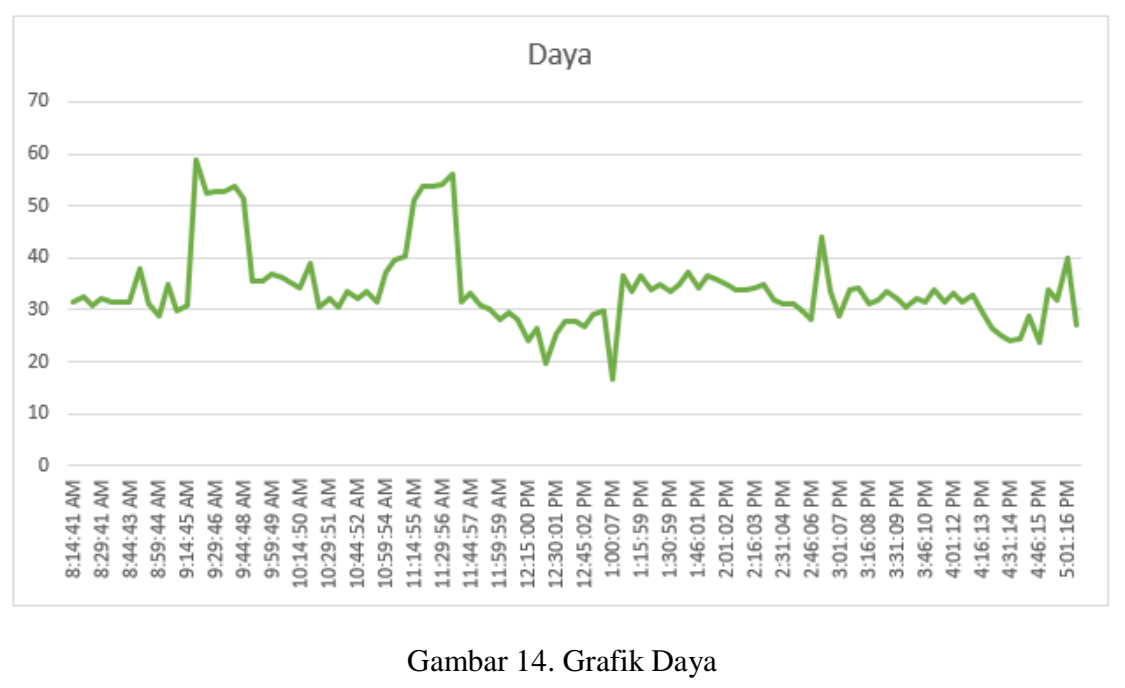

Grafik daya didapatkan dari $P=V \times I$ pada pukul 8:14 daya yang dihasilkan 31 $\mathrm{W}$ dan pada akhir pengambilan data pada pukul 5:01 daya yang dihasilkan panel surya yaitu $27 \mathrm{~W}$. Pada rentang waktu tersebut terdapat penambahan dan pengurangan daya 
seperti yang kita lihat pada gambar 14. Hal ini disebabkan oleh kenaikan dan penuruna dari sensor arus dan sensor tegangan.

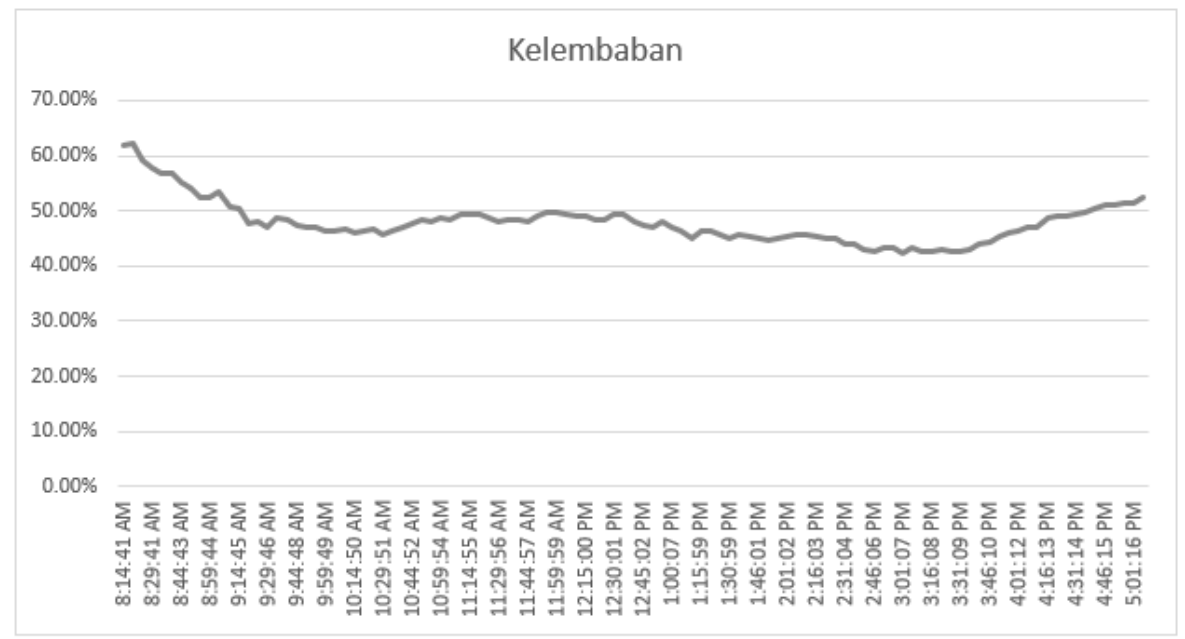

Gambar 15. Grafik kelembaban

Seperti yang dilihat pada gambar 15 pada pagi hari pukul 8:14 sensor DHT22 menunjukan kelembaban berada pada $61 \%$, menurut prinsipnya kelembaban akan sangat rendah pada kisaran pukul 12:00, hal ini dikarenakan beberapa faktor yng disebabkan oleh cuaca. Kemudian pada akhir pengambilan data pada pukul 5:01 kelembaban menunjukan $51 \%$, sehingga kinerja pada sore hari dari panel surya sudah tidak optimal.

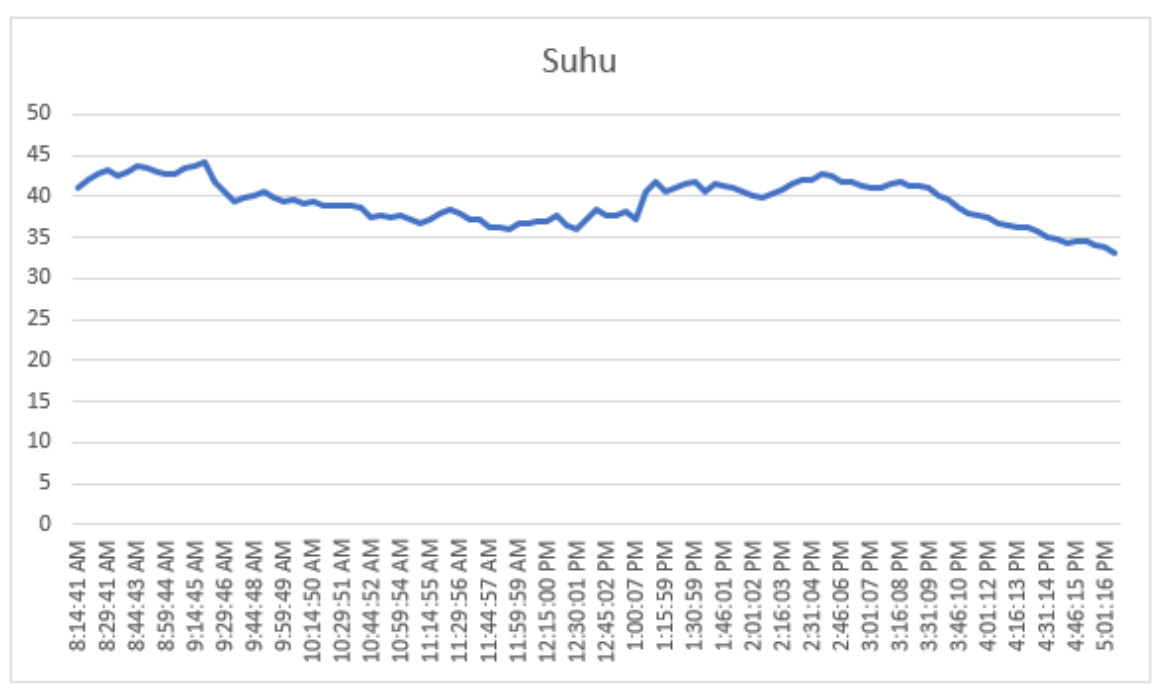

Gambar 16. Grafik Suhu

Seperti yang dilihat pada grafik, pada awal pengambilan data pada pukul 8:14 sensor DHT22 menunjukan suhu pada $41^{\circ} \mathrm{C}$ kemudian dakhir pengambilan data menunjukan $34^{\circ} \mathrm{C}$ kenaikan dan penurunan tersebut disebabkan oleh keadaan cuaca, hal tersebut sangat berpengaruh pada penyerapan panel surya. 


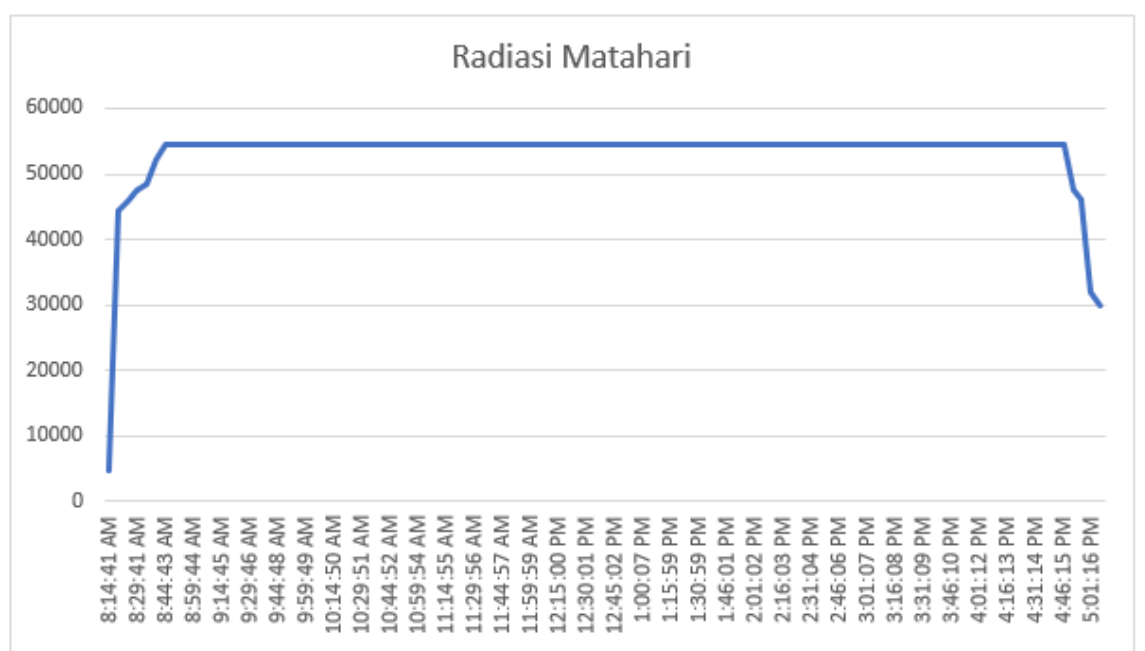

Gambar 17. Grafik Radiasi Matahari

Seperti yang dilihat pada gambar 17 radiasi matahari yang dihasilkan sensor BH1750 menunjukan nilai maksimal pada 54612.50 lux hal ini dikarenakan kemampuan maksimal sensor BH1750 dalam menangkap LUX dari radiasi matehari.

\section{Pembahasan}

Pada penelitian sebelumnya yang berjudul Wireless Monitoring System For Photovoltaic Generation With Graphical User Interface hasil penelitian menunjukkan bahwa sistem yang dibangun dapat memantau parameter panel surya berupa tegangan, arus dan suhu secara real time. Perbedaannya penelitian kali ini menambahkan menggunakan sistem tracker untuk menggerakan panel dari timur ke barat, selatan ke utara dari panel surya. Setelah Melakukan pengujian dan pengambilan data dari panel surya yang menggunakan sistem tracker dual axsis, maka didapat hasil dari beberapa sensor seperti arus, tegangan, suhu, kelembaban, secara real time dengan pembacaan data menggunakan PLX DAQ yang menunjukan adanya peningkatan efisiensi kerja dari panel surya.

Pada saat awal pengambilan data pada pukul 8.14 WIB daya dari panel surya menunjukan $31 \mathrm{~W}$ dan pada pukul 5.01 WIB pada $27 \mathrm{~W}$, ini adalah pembuktian dari pembacaan sensor yang menunjukan efisiensi dari panel surya dalam menyerap energi, . Kekurangan dari sistem ini yaitu, tuas pendorong actuator yang digunakan sebagai penggerak tidak begitu panjang sehingga tidak bisa menggerakan panel menuju ke sudut $90^{\circ}$, kemudian pada pembacaan sensor radiasi matahari memiliki kapasitas 54612.50 Lux, sehingga untuk pembacaan radiasi matahari tidak begitu efisiensi.

\section{KESIMPULAN}

Dari hasil penelitian dan pengujian yang dilakukan mulai tahap awal hingga proses pengujian Sistem Monitoring Kinerja Panel Listrik Tenaga Surya dapat disimpulkan bahwa pengukuran karakteristrik panel surya berbasis PLX DAQ dapat diimplementasikan dengan baik. Kemudian nilai yang terukur ditentukan oleh kondisi 
lingkungan, ketika matahari bersinar akan ada penambahan daya yang dihasilkan, sebaliknya jika cuaca mendung maka daya yang dihasilkan panel surya tidak optimal.

\section{REFERENSI}

[1] S. Salam and H. Mubarok, "Monitoring Output Daya Prototype Solar Tracker Dual Axsis Menggunakan Web Server Berbasis Arduino," J. Tek. Elektro, Univ. Islam Indones., pp. 1-6, 2019.

[2] A. N. Achadiyah, M. Suseno, and A. Sari, "Perancangan Solar Tracker Photovoltaic Cells Dengan Metode Fuzzy Logic," G-Tech J. Teknol. Terap., vol. 2, no. 2, pp. 37-41, 2019.

[3] Krismadinata, Asnil, H. Irma, and Hendri, "Microcontroller based multilevel inverter for photovoltaic system," Adv. Sci. Lett., vol. 23, no. 5, pp. 3859-3863, 2017.

[4] E. Martha, A. Asnil, and F. Eliza, "Sistem Pengisian Baterei Menggunakan Buck Konverter," INVOTEK J. Inov. Vokasional dan Teknol., vol. 18, no. 1, pp. 117124, 2018.

[5] B. Maharmi, F. Ferdian, and F. Palaha, "Sistem Akuisisi Data Solar Cell Berbasis Mikrokontroler dan Labview," SainETIn, vol. 4, no. 1, pp. 19-24, 2019.

[6] A. PUDIN and I. R. MARDIYANTO, "Desain dan Implementasi Data Logger untuk Pengukuran Daya Keluaran Panel Surya dan Iradiasi Matahari," ELKOMIKA J. Tek. Energi Elektr. Tek. Telekomun. Tek. Elektron., vol. 8, no. 2, p. 240, 2020.

[7] R. R. A. Siregar and N. Wardana, "SISTEM MONITORING KINERJA PANEL LISTRIK TENAGA SURYA MENGGUNAKAN ARDUINO UNO," JETri, vol. 14, pp. 81-100, 2017.

[8] A. Asnil, K. Krismadinata, I. Husnaini, and F. Gunawan, "Wireless Monitoring System For Photovoltaic Generation With Graphical User Interface," Int. J. pf Sci. Technol. Res., vol. 9, no. 08, pp. 1-6, 2020.

[9] Putriani, M. Basyir, and Muhaimin, "Sistem Monitoring Alat Uji Karakteristik Panel Surya Berbasis Mikrokontroler,” J. Tektro, vol. 3, no. 2, pp. 102-112, 2019.

[10] Krismadinata, R. Lapisa, Syahril, and Asnil, "Characteristic comparison of photovoltaic module and photovoltaic thermal," MATEC Web Conf., vol. 204, pp. $1-6,2018$.

[11] Pande Putu Teguh Winata, Wayan Arta Wijaya, Made Suartika. "Rancang Bangun Sistem Monitoring Output dan Pencatatan Data pada Panel Surya Berbasis Mikrokontroler Arduino.” E-Journal SPEKTRUM, Vol. 3, No. 1, Juni 2016.

[12] M. Fuentes, M.Vivar, J.M.Burgos, J.Aguilera, J.A.Vacas. "Design of an accurate, low-cost autonomous data logger for PV system monitoring using Arduino that complies with IEC standards.” Solar Energy Materials \& Solar Cells, 130, pp. 529-543, 2014. 
[13] Yansen. "Data Logger Parameter Panel Surya." Tugas Akhir. Fakultas Elektronika dan Komputer, Universitas Kristen Satya Wacana, Salatiga, Indonesia, 2013.

[14] M. R. Fachri, I. D. Sara, and Y. Away, "Pemantauan Parameter Panel Surya Berbasis Arduino secara Real Time," J. Rekayasa Elektr., vol. 11, no. 4, pp. 123, 2015.

[15] W. Yandi, "Prototipe Data Logging Monitoring System Untuk Konversi Energi Panel Surya Polycrystalline $100 \mathrm{Wp}$ Berbasis Arduino Uno," J. Ecotipe (Electronic, Control. Telecommun. Information, Power Eng., vol. 7, no. 1, pp. 55-60, 2020. 